\title{
A Dynamic Study of Earthworm Feeding Ecology Using Stable Isotopes
}

\author{
M. J. I. Briones ${ }^{1}$, R. Bol ${ }^{2}$, D. Sleep ${ }^{3}$, L. Sampedro ${ }^{1}$ and D. Allen ${ }^{4}$ \\ ${ }^{1}$ Departamento de Ecología y Biología Animal, Facultad de Ciencias, Universidad de Vigo, E-36200 Vigo, Spain \\ ${ }^{2}$ Institute of Grassland and Environmental Research, North Wyke Research Station, Okehampton, Devon EX20 2SB, UK \\ ${ }^{3}$ Merlewood Research Station, Institute of Terrestrial Ecology, Grange-over-Sands, Cumbria LA11 6JU, UK \\ ${ }^{4}$ Institute of Grassland and Environmental Research, Aberwystwyth, Plas Gorgeddon, Ceridigion SY23 3RD, UK
}

\begin{abstract}
Changes in the specific diet of earthworms with time in relation to landuse changes and two different climates were studied by analysing ${ }^{13} \mathrm{C}$ and ${ }^{15} \mathrm{~N}$ natural abundance in soils and animals. Soil samples from three depths $(0-10,10-20$ and $20-30 \mathrm{~cm})$ and earthworms were collected from two sites: Santiago (Northwest Spain) and North Wyke (Southwest England) both consisting of replicated long-term grasslands and recently converted to maize plots. Earthworms were hand-sorted in the field at the peak of the maize growth and after harvesting at both sites.

In the Spanish plots, nine and eight earthworm species, all belonging to the three ecological categories (epigeic, anecic and endogeic), were found under maize and permanent pasture, whereas at the English site five and seven different species were, respectively, identified. At both sites ${ }^{13} \mathrm{C}$ isotopic values of the earthworm tissues reflected changes in diet from $C_{3}$ to $C_{4}$ with epigeic and epi/anecic worms in the maize plots showing one delta unit difference in relation to the ones found in the grassland plots. Anecic worms seemed to be less responsive to landuse changes. The higher ${ }^{13} \mathrm{C}$ values of the Spanish soils were also reflected in the earthworm tissues when compared with the English samples.

${ }^{15} \mathrm{~N}$ values showed no clear relationship with the cropping treatments but were clearly related to the ecological grouping, with endogeic worms reaching the highest values whereas for the epigeic and epi/ anecic species the lowest values were obtained. This finding was also previously recorded by other authors ${ }^{1}$ and suggests that, in the future, stable isotope techniques could also be a useful tool in taxonomic studies. Copyright (C) 1999 John Wiley \& Sons, Ltd.
\end{abstract}

Received 26 January 1999; Revised 20 April 1999; Accepted 23 April 1999

It is generally accepted that earthworm species can be classified into three ecological categories according to their feeding behaviour ${ }^{2-4}$ epigeic species (living in the upper soil layers), endogeic species (deep borrowers) and anecic species (moving through the soil profile). However, it is unlikely that all earthworm species will fall neatly into any of these three categories and any factor affecting their feeding strategies can therefore modify these ecological strategies. In this sense, landuse changes and global warming are assumed to have a potential impact on the soil fauna communities.

Studies on the feeding habitats of earthworms usually rely on direct observations of the feeding activity, microbiological analyses of gut contents, palatability tests, recording ingestion and consumption rates and measurements of the growth rates of the worms growing on different substrates. However, the isotopic composition of the whole body in small animals gives an accurate estimate of the $\delta$ value of their diet because of the short time period for assimilation processes $^{5}$ and, therefore, isotopic techniques can be a powerful tool in determining food preferences as they are less time consuming.

Research studies involving natural abundance of stable

*Correspondence to: M. J. I. Briones, Departamento de Ecología y Biología Animal, Facultad de Ciencias, Universidad de Vigo, E-36200 Vigo, Spain

E-mail: mbriones@uvigo.es isotopes of carbon and nitrogen to determine the dietary preferences of different animal species have been successfully used in the past for vertebrates, ${ }^{6,7}$ but there have been an increasing number of studies performed on invertebrates, ${ }^{1,8-13}$ mainly on earthworms.

When compared to long-term pastures, earthworm populations under long-term arable crops are generally smaller and their specific composition is modified due to mechanical damage during cultivation, to the loss of the insulating layer of vegetation, to predation by birds when worms are brought to the surface during cultivation or to a reduction in organic matter available as a food source. ${ }^{14}$ In this paper we used stable isotopic ${ }^{13} \mathrm{C}$ and ${ }^{15} \mathrm{~N}$ techniques to clarify changes in the specific diet, habitat and soil organic matter pools assimilated by earthworms in relation to landuse changes in order to optimize agro-ecological management to improve soil fertility.

\section{MATERIALS AND METHODS}

\section{Sampling}

The study involved two sites: Neiro, Santiago de Compostela, Spain (UTM Grid. Ref. 29TNH07) and North Wyke, Okehampton, Devon, England (Nat. Grid. Ref. SX 649 993) both consisting of long-term grasslands and recently converted to maize plots. Samples were taken at the peak of the maize growth (10/11/97) in Spain and after the maize 
Table 1. $\delta^{13} \mathrm{C}$ values in soils from the maize $(\mathrm{n}=6)$ and grassland plots $(\mathrm{n}=3)$ at the different depths and sampling dates at both sites and results from one-way ANOVA with different letters indicating significant differences between depths (Tukey grouping $\dagger, p<0.05$ )

\begin{tabular}{|c|c|c|c|c|c|c|c|c|c|}
\hline \multicolumn{6}{|c|}{ Spain } & \multicolumn{4}{|c|}{ England } \\
\hline & & $10 / 11 / 97$ & $20 / 12 / 97$ & $20 / 02 / 98$ & 04/05/98 & & & $20 / 11 / 97$ & $28 / 04 / 98$ \\
\hline \multirow{3}{*}{ Maize } & $0-10 \mathrm{~cm}$ & $-26.12 \mathrm{a}$ & $-25.88 \mathrm{a}$ & $-25.91 \mathrm{a}$ & $-26.02 \mathrm{a}$ & \multirow{3}{*}{ Maize } & $0-10 \mathrm{~cm}$ & $-29.51 \mathrm{a}$ & $-28.65 \mathrm{a}$ \\
\hline & $10-20 \mathrm{~cm}$ & $-25.85 a b$ & $-26.04 \mathrm{a}$ & $-26.11 \mathrm{a}$ & $-26.14 \mathrm{a}$ & & $10-20 \mathrm{~cm}$ & $-28.78 \mathrm{ab}$ & $-28.60 \mathrm{a}$ \\
\hline & $0-10 \mathrm{~cm}$ & $-26.29 \mathrm{a}$ & $-26.50 \mathrm{a}$ & $-26.40 \mathrm{a}$ & $-26.25 \mathrm{a}$ & & $0-10 \mathrm{~cm}$ & $-29.66 \mathrm{a}$ & $-29.11 \mathrm{a}$ \\
\hline \multirow[t]{2}{*}{ Grassland } & $10-20 \mathrm{~cm}$ & $-25.86 \mathrm{ab}$ & $-25.85 b$ & $-25.68 b$ & $-25.90 \mathrm{a}$ & \multirow[t]{2}{*}{ Grassland } & $10-20 \mathrm{~cm}$ & $-29.26 \mathrm{a}$ & $-29.21 \mathrm{a}$ \\
\hline & $20-30 \mathrm{~cm}$ & $-25.39 b$ & $-25.48 b$ & $-25.57 b$ & $-25.60 \mathrm{a}$ & & $20-30 \mathrm{~cm}$ & $-28.64 \mathrm{a}$ & $-28.96 \mathrm{a}$ \\
\hline
\end{tabular}

$\dagger$ See for example, Statistical Books, Winer 1971, Sokal and Rohlf 1981, Day and Quinn 1989.

Table 2. Earthworm species and ecological category for each treatment at both sites $(\mathrm{END}=$ endogeic, ANE $=$ anecic, EPI $=$ epigeic, EPI/ $\mathrm{ANE}=$ epi/anecic)

\begin{tabular}{|c|c|c|c|c|c|c|c|}
\hline \multicolumn{4}{|c|}{ Spain } & \multicolumn{4}{|c|}{ England } \\
\hline \multicolumn{2}{|l|}{ Maize } & \multicolumn{2}{|l|}{ Grassland } & \multicolumn{2}{|l|}{ Maize } & \multicolumn{2}{|l|}{ Grassland } \\
\hline Allolobophora caliginosa & END & Allolobophora caliginosa & END & Allolobophora caliginosa & END & Allolobophora caliginosa & END \\
\hline A. trapezoides & ANE & A. trapezoides & ANE & A. rosea & END & A. rosea & END \\
\hline A. rosea & END & A. rosea & END & A. chlorotica & END & A. chlorotica & END \\
\hline Dendrobaena madeirensis & END & Dendrobaena madeirensis & END & A. longa & ANE & A. longa & ANE \\
\hline D. octaedra & EPI & D. octaedra & EPI & & & D. mammalis & EPI \\
\hline D. rubida & EPI & & & L. rubellus & EPI & L. rubellus & EPI \\
\hline Octolasion cyaneum & END & Octolasion cyaneum & END & & & & \\
\hline Eiseniella tetraedra & EPI & Eiseniella tetraedra & EPI & & & & \\
\hline
\end{tabular}

had been harvested at both sites (20/02/97, 20/02/98 and 04/05/98 in Spain; 20/11/97, 28/01/98 and 28/04/98 in England).

On every sampling occasion, soil and earthworm samples were taken from both grassland and maize plots at the two sites. Earthworms were hand-sorted in the field and then taken back to the laboratory for identification to species level, dissected to remove the guts and rapidly frozen to $-10^{\circ} \mathrm{C}$ until further analysis. In the case of soil samples, each plot was subdivided into three subplots and a soil sample from three different depths $(0-10,10-20$ and 20$30 \mathrm{~cm}$ ) was taken from each treatment (three replicate soil samples), but in the maize plots replicate soil samples were taken along the row of maize plants and between rows of plants following the same procedure. Soil samples were oven-dried to $65^{\circ} \mathrm{C}$ to constant weight for seven days.

\section{Isotopic analysis}

Earthworms from each species and from every treatment, sampling date and site were bulked and freeze-dried for $\mathrm{N}$ and $\mathrm{C}$ isotopic analysis, whereas the replicate soil samples were only analysed for ${ }^{13} \mathrm{C}$ (only two dates for the English samples).

All samples (bulked animal and replicate soil samples) were ground to a homogeneous powder using a SPEX liquid nitrogen cooled mill (Glen Creston Ltd., Stanmore, Middlesex, UK) before being weighed using a micro-balance to ensure sufficient dry-weight for each sample for analyses. Earthworm samples were sealed into $6 \times 4 \mathrm{~mm}$ tin capsules prior to separate $\mathrm{C}$ and $\mathrm{N}$ isotopic analyses at Merlewood, using an ANCA-MS system (Europa Scientific Ltd, Crewe, Cheshire, UK); this analytical system is fully described by Barrie and Prosser. ${ }^{15}$ Beet sucrose was used as a reference material for C, at $-25.96 \%$, relative to Pee Dee Belemnite
(PDB). Ammonium sulphate, at $+1.74 \%$ relative to air (atmospheric N), was employed for N. Analytical precision over 10 replicates of both standards was better than $0.2 \%$.

Soil samples were analysed at Aberystwyth against a Europa flour standard $\delta^{13} \mathrm{C}=-25.34 \%$.

\section{Statistical analysis}

Comparisons between treatments and sites were made using analysis of variance (ANOVA), using one-way ANOVA to compare mean isotopic values per treatment at the different sites. Two-way ANOVA was used to quantify interactions between sites, treatments, soil depths and sampling dates.

\section{RESULTS}

At both sites, no significant differences were found between the two sampling procedures adopted for the maize plots and therefore soil data from 'along-row' and 'inter-row' treatments were combined into one ('maize') for the statistical analyses.

Spanish soils significantly $(\mathrm{p}<0.05)$ contained more carbon (7\%) than the English ones (2.7\%) and also showed a higher ${ }^{13} \mathrm{C}$ enrichment $(-25.85)$ which was significantly different to the mean isotopic value recorded for the English soils (-28.80). Additionally, at both sites, an increase in ${ }^{13} \mathrm{C}$ with depth was observed, mainly in the grassland plots which were not rotavated (Table 1), but differences were only significant at the Spanish site $(\mathrm{p}<0.05)$. Date and site, together with the interaction site and treatment, also had a significant effect on $\delta^{13} \mathrm{C}$ values of the soils at both sites and, within each site, significant interactions were detected for some of the variables analysed (depth and treatment for Spain and depth and date for England).

In the Spanish plots, nine and eight earthworm species, all 
(a)

SPAIN (10/11/97)

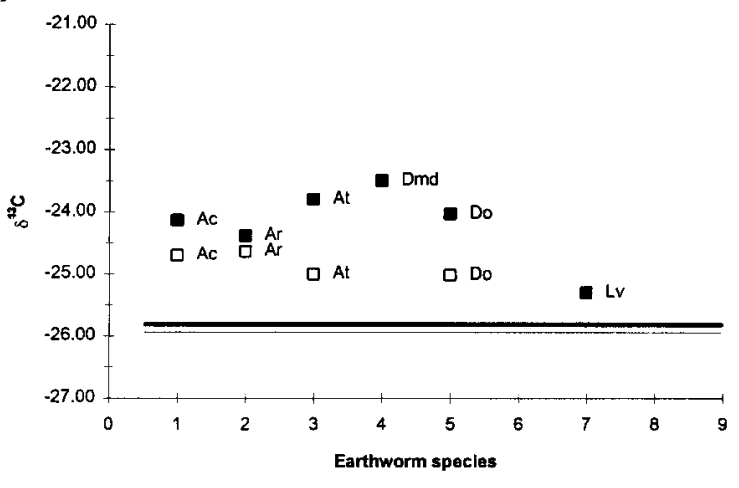

SPAIN (20/12/97)
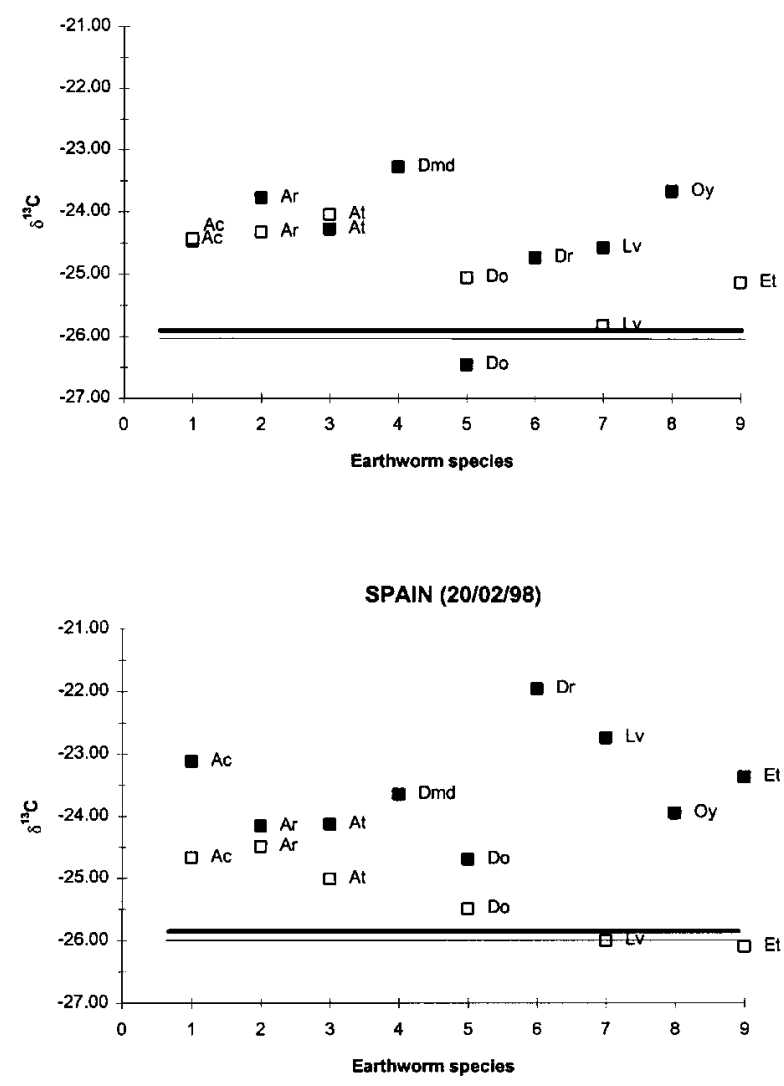

SPAIN (04/05/98)

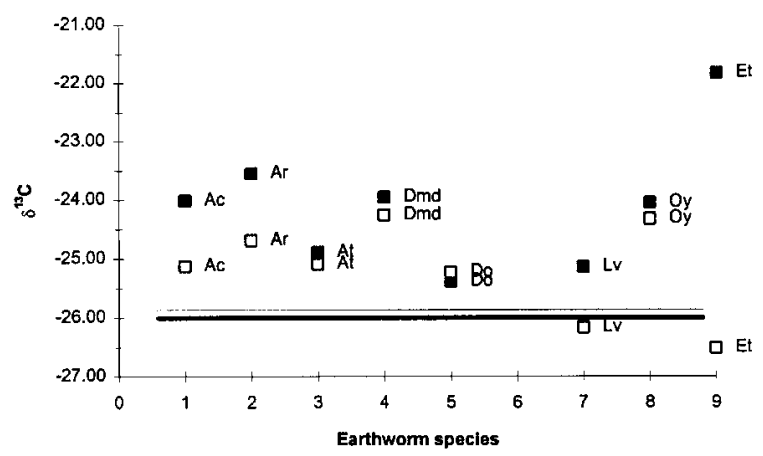

(b)

ENGLAND (20/11/97)

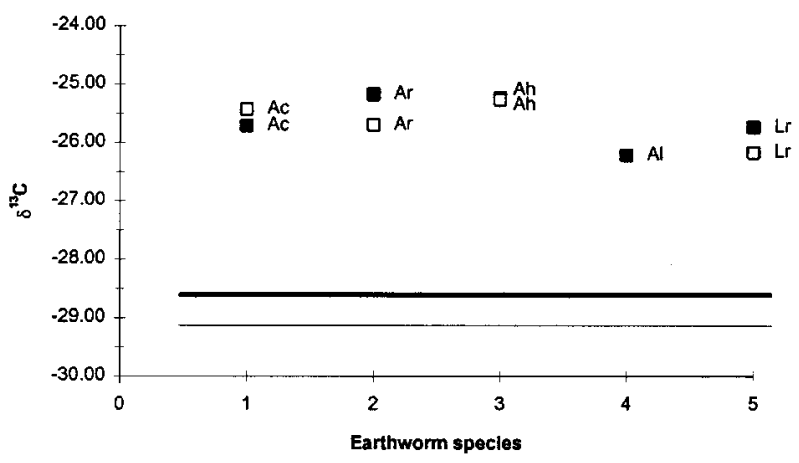

ENGLAND (28/04/98)

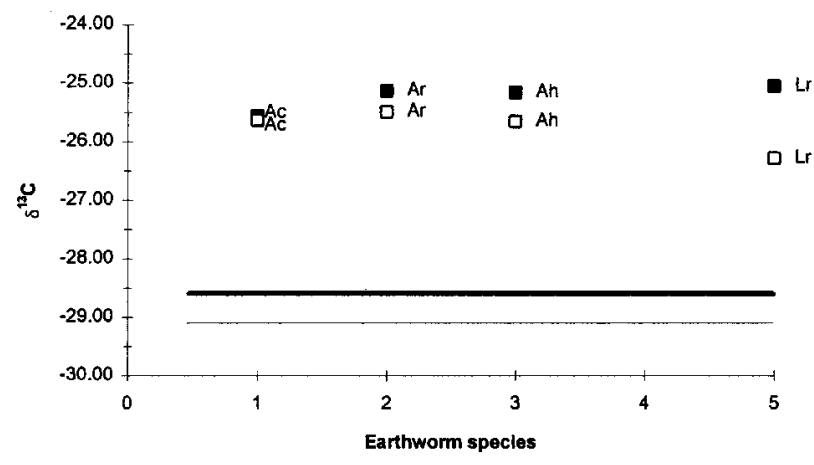

Figure 1. Changes in the $\delta^{13} \mathrm{C}$ values of the earthworm species in the maize ( $\square$ ) and grassland $(\square)$ plots and mean $\delta^{13} \mathrm{C}$ values of soils from maize (thick line) and grassland plots (fine line) at the different dates in Spain (a) and England (b). Species abbreviations: Ac = Allolobophora caliginosa, $\mathrm{Ah}=$ Allolobophora chlorotica, $\mathrm{Al}=$ Allolobophora longa, $\mathrm{Ar}=$ Allolobophora rosea, $\mathrm{At}=$ Allolobophora trapezoides, $\mathrm{Dm}=$ Dendrobaena mammalis, Dmd = Dendrobaena madeirensis, Do = Dendrobaena octaedra, $\mathrm{Dr}=$ Dendrobaena rubida, $\mathrm{Et}=$ Eiseniella tetraedra $\mathrm{Lr}=$ Lumbricus rubellus, $\mathrm{Lt}=$ Lumbricus terrrestris, $\mathrm{Lv}=$ Lumbricus festivus, $\mathrm{Oy}=$ Octolasion cyaneum . 
SPAIN

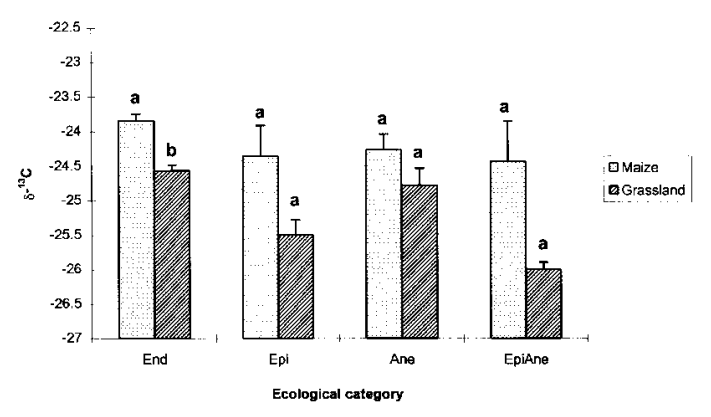

SPAIN

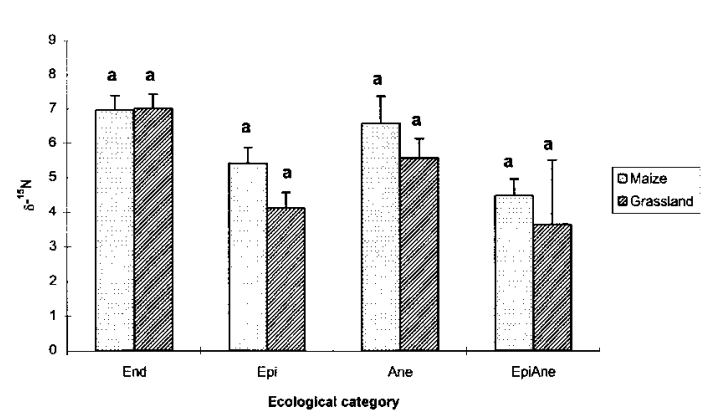

ENGLAND

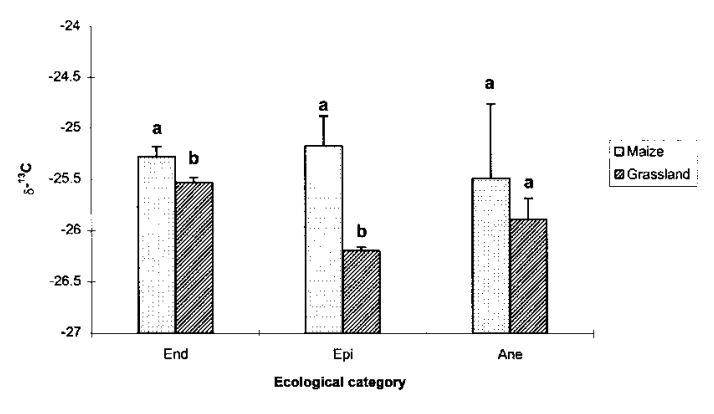

ENGLAND

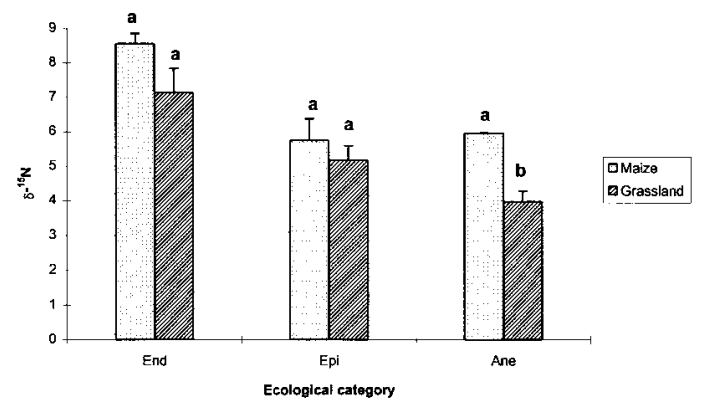

Figure 2. $\delta^{13} \mathrm{C}$ (a) and $\delta^{15} \mathrm{~N}$ (b) mean values with standard errors of the different ecological categories at each site and results from one-way ANOVA with different letters indicating significant differences between treatments (Tukey grouping, $\mathrm{p}<0.05)$. Number of observations for each ecological group at the two sites are as follows: Spain: End = 15 (maize) $/ 10$ (grassland), Epi $=8$ (maize) $/ 7$ (grassland), Ane = 4, EpiAne = 4 (maize)/3 (grassland); England: End = 9, Epi = 3 (maize)/4 (grassland), Ane = 2 .

belonging to the three ecological categories (epigeic, anecic and endogeic), were found under maize and permanent pasture, whereas at the English site five and seven different species were, respectively, identified (Table 2).

Figure. 1 shows the changes in the $\delta^{13} \mathrm{C}$ values of the earthworm species and the soils (since there were only two dates when depths were significantly different, the mean for the three layers is given) at the different dates and sites. It can be seen that the higher ${ }^{13} \mathrm{C}$ values of the Spanish soils are also reflected in the earthworm tissues when compared with the English samples. At both sites, stable $\mathrm{C}$ isotope ratios in the earthworm tissues reflect changes in diet from $\mathrm{C}_{3}$ to $\mathrm{C}_{4}$, it being possible in most cases to distinguish between specimens belonging to the same species but feeding on different labeled material. This was particularly clear at the English site (Fig. 1(b)) where the earthworm species collected on both sampling dates showed a uniform pattern of isotopic values with time. However, at the Spanish site (Fig. 1(a)), $\delta^{13} \mathrm{C}$ values of earthworm tissues showed a higher variation with time, and on some occasions it was not possible to differentiate between treatments (e.g. A. caliginosa on 20/12/97). Initially, before the maize was cut, earthworms seemed to respond to the new organic material by showing less negative $\delta^{13} \mathrm{C}$ values. Just after the maize had been harvested, only endogeic species seemed to have a clear preference for the organic material derived from the maize, but after two months the whole earthworm community showed a distinctive response to the $\mathrm{C}_{4}$ material which again becomes diluted at the end of the experimental period.

From Fig. 1 it can also be stated that fractionation effects were higher at the English plots, up to 3.0 delta units, than in
Spain, where a difference up to 2 delta units between the earthworms and the feed was observed.

When earthworms were grouped according to the three ecological categories (epigeic, endogeic and anecic), plus the epi/anecic L. festivus at the Spanish plots (Fig. 2), there was a significant effect $(\mathrm{p}<0.05)$ of the ecological grouping on $\delta^{13} \mathrm{C}$ values only at the Spanish site, with endogeic species being significantly different to epi/anecic ones. The treatment effect was only observed for endogeic species at both sites and for epigeic species at the English site (Fig. 2(a)). $\delta^{15} \mathrm{~N}$ values were also affected by the ecological grouping, with endogeic species being significantly different to epigeic species at both sites and epi/ anecic species being different to endogeic and anecic species in Spain and anecic species different to endogeic species in England $(\mathrm{p}<0.05)$. Treatment had a significant effect on $\delta^{15} \mathrm{~N}$ values for anecic species at the English site only (Fig. 2(b)).

\section{DISCUSSION}

Spanish species showed a higher enrichment in ${ }^{13} \mathrm{C}$ when compared to English populations, which can be explained as a result of the different fractionation values of the earthworm tissues in relation to their feeds and the different isotopic values recorded for the soils. Under different climates soil turnover has a strong effect on mineralization rates and is therefore a factor to be taken into account when comparing sites.

Epigeic and epi/anecic worms were the most responsive species to landuse changes and, at both sites, ${ }^{13} \mathrm{C}$ isotopic values of the earthworm tissues reflected changes in diet 
from $\mathrm{C}_{3}$ to $\mathrm{C}_{4}$, up to one delta unit difference in the worms feeding in the maize plots when compared with the ones found in the grassland plots. This represents a larger enrichment than that found in the soils $\mathrm{C}_{4}$ versus $\mathrm{C}_{3}$, and indicates a preference by the worms for $\mathrm{C}_{4}$ fresh new residue over older native $\mathrm{C}_{3}$ soil organic matter. However, there was also a large contribution of $\mathrm{C}_{3}$ material in the earthworm tissues indicating that the animals were also feeding on $\mathrm{C}$ derived from the original grass pasture before conversion to maize. Additionally, $\delta{ }^{13} \mathrm{C}$ values of the earthworm species showed some variability with time, which highlights the importance of chronosequence studies to a better understanding of the feeding behaviour of the populations, and could be indicating movements through the soil profile (probably according to weather) and a more diversified feeding. In relation to the latter, Lattaud et al. ${ }^{16}$ found that geophagous endogeic worms display variable digestive capacities based on ingested bacteria or on symbiosis relationships, but for the rest of earthworm groups similar strategies have only been identified in the epigeic L. rubellus. ${ }^{17}$

${ }^{15} \mathrm{~N}$ values showed no clear relationship with the cropping treatments but trophic positions have been successfully determined using $\delta^{15} \mathrm{~N}$ values, with endogeic species showing the highest ${ }^{15} \mathrm{~N}$ enrichment whereas for epigeic and anecic worms the lowest values were recorded. This was also previously observed ${ }^{1}$ and means that endogeic species feed on more mineralised organic matter whereas epigeic and anecic worms prefer less microbially processed material.

Very little information is available on $\mathrm{C}$ assimilation efficiency and virtually no data on $\mathrm{N}$ assimilation rates in earthworms. ${ }^{18}$ Our study demonstrates that there is a selective feeding by earthworms and, thus, our populations assimilated a relatively higher proportion of $\mathrm{C}_{4}$ than $\mathrm{C}_{3}$ material and the different ecological categories appeared to consume organic material of different quality, proving that combined $\mathrm{C}$ and $\mathrm{N}$ isotope analysis constitutes a powerful tool in studying feeding ecology. However, these kind of approaches should be extended to other earthworm species in a wide range of habitats and climates to get a more complete knowledge of the role of earthworms on nutrient cycling as there seems to be some evidence for direct linking between global change, soil biodiversity and nutrient cycling. ${ }^{19}$

Additionally, isotopic techniques could, in the future, help in taxonomic studies as current tendencies claim a more functional classification of soil fauna ${ }^{20}$ and, according to this classification, a functional group is a group of organisms which affect a process in a similar way. Therefore, isotope values of the animal tissues could supply valuable information in order to identify a list of organisms with a similar function in the soil system.

Also, in relation to this, some studies claim a revision of the earthworm ecological groupings at least for tropical species. $^{21-23}$ In these systems endogeic species are dominant and their feeding strategies fall in between epigeic and endogeic species, possibly as a result of evolution of the earthworm communities in response to vegetation, geography and climate of these particular regions. ${ }^{14}$
This study also showed variation of the earthworms feeding activity with time which has also been recently observed by Neilson et al. ${ }^{24}$ and emphasises the need for long-term studies to better understand the effects of earthworms on the biogeochemical cycles both in natural and agroecosystems. This kind of information could be very useful in running simulation models of organic matter which should include not only the earthworms (typically ignored in these models) but also the temporal and spatial scales, particularly when addressing the potential effects of the driving global forces, such as climate change and landuse, on the soil ecosystem.

\section{Acknowledgements}

M. J. I. Briones and L. Sampedro would like to thank Mr. Arturo Zas and Mr. Rafael Zas for the field facilities to carry out this project and to the Biochemistry and Plant Physiology laboratories at the University of Vigo for the freeze-drying equipment.

\section{REFERENCES}

1. O. Schmidt, C. M. Scrimgeour and L. L. Handley, Soil Biol. Biochem. 29, 1301 (1997).

2. M. B. Bouché, Lombriciens de France. Ecologie et Systématique, Institut National de la Recherche Agronomique, Paris (1972).

3. K. E. Lee, Earthworms: Their Ecology and Relationships with Soils and Land Use, Academic Press, Sydney (1985).

4. P. Lavelle, E. Blanchart, A. Martin, S. Martin, A. V. Spain, F. Toutain, I. Barois and R. Schaefer, Biotropica 25, 130 (1993).

5. M. J. DeNiro and S. Epstein, Geochim. Cosmochim. Acta 42, 495 (1978).

6. M. J. DeNiro and S. Epstein, Science 201, 906 (1978).

7. L. L. Tieszen, D. Hein, S. A. Qvortrup, J. H. Troughton and S. K. Imbamba, Oecologia 37, 351 (1979).

8. A. V. Spain, P. G. Saffigna and A. W. Wood, Soil Biol. Biochem. 22, 703 (1990).

9. A. Martin, A. Mariotti, J. Balesdent and P. Lavelle, Ecology 73, 118 (1992).

10. A. Martin, J. Balesdent and A. Mariotti, Oecologia 91, 23 (1992).

11. A. V. Spain and P. Reddell, Soil Biol. Biochem. 28, 1585 (1996).

12. A. V. Spain and R. Le Feuvre, Biol. Fertil. Soils 24, 118 (1997).

13. M. J. I. Briones, P. Ineson and D. Sleep, Soil Biol. Biochem. 31, 937 (1999).

14. C. A. Edwards and P. J. Bohlen, Biology and Ecology of Earthworms, Chapman and Hall, London (1996).

15. A. Barrie and S. J. Prosser, in Mass Spectrometry of Soils, T. W. Boutton and S. Yamasaki (Eds), Marcel Dekker Inc., New York, pp. 1-46 (1996).

16. C. Lattaud, S. Locati, P. Mora, C. Rouland and P. Lavelle, Appl. Soil. Ecol. 9, 189 (1998).

17. F. Urbasek, Rev. Ecol. Biol. Sol 27, 21 (1990)

18. R. W. Parmelee, P. J. Bohlen and M. Blair, in Earthworm Ecology, C. A. Edwards (Ed.), St. Lucie Press, Boca Raton, Florida, pp. 123-143 (1998).

19. M. J. Swift, O. Andrén, L. Brussaard, M. J. I. Briones, M. M. Couteaux, K. Ekschmitt, A. Kjoller, P. Loiseau and P. Smith, Global Change Biology 4, 729 (1998).

20. B. S. Griffiths, in Functional Implications of Biodiversity in Soil, V. Wolters (Ed.), European Commission, Ecosystems Research Report 24, Belgium, pp. 13-16 (1997).

21. P. Lavelle, Rev. Ecol. Biol. Sol 16, 85 (1979).

22. P. Lavelle, Biol. Fertil. Soils 6, 237 (1988).

23. P. F. Hendrix, in Earthworm Ecology, C. A. Edwards (Ed), St. Lucie Press, Boca Raton, Florida, pp. 259-269 (1998).

24. R. Neilson, D. Hamilton, J. Wishart, C. A. Marriott, B. Boag, L. L. Handley, C. M. Scrimgeour, J. W. McNicol and D. Robinson, Soil. Biol. Biochem. 30, 1773 (1998). 